\title{
Skilled labour supply in the South African construction industry: The nexus between certification, quality of work output and shortages
}

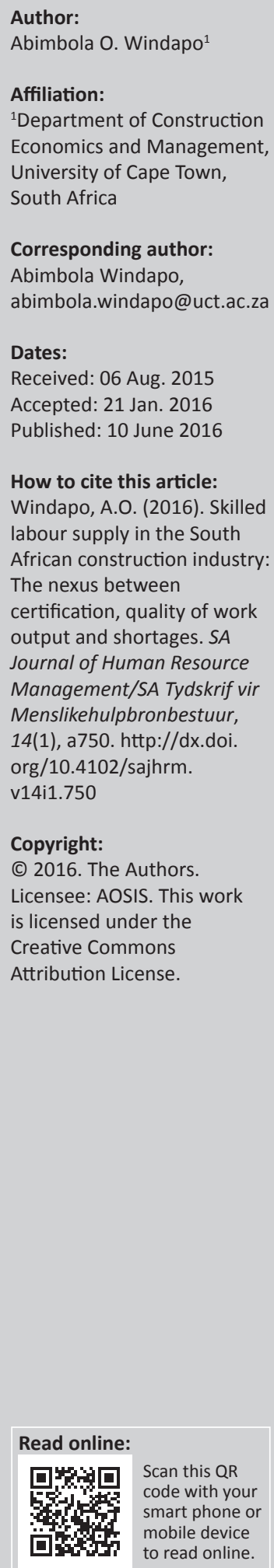

Orientation: Construction human resource management.

Research purpose: The study examines the skilled labour supply in the South African construction industry and determines whether there is a relationship between trade certification, quality of work output and scarce labour skills.

Motivation for the study: The rationale for the investigation is based on the view of scholars that a skilled labour shortage is preponderant in the South African construction industry even though there is a high level of youth unemployment in South Africa and that the perceived skills shortage contributes to a decrease in productivity and product quality.

Research design, approach and method: The paper reviews relevant literature and employs a mixed method research approach in collecting empirical data from contracting companies within the Western Cape Province of South Africa that are listed on the Construction Industry Development Board contractor register.

Main findings: The study demonstrated that there is no shortage of manpower, but there is a shortage of qualified or skilled tradesmen, such as electricians, plumbers, welders, fitters and carpenters, whose professions are more technical and require formal training and certification. The level of supply of skilled tradesmen is attributed to the lack of high-quality basic education, the state of the economy, compulsory certification of tradesmen and an ageing workforce. It was also found that there is a significant relationship between skilled labour shortages and the requirement that labour be certified and that work output is unsatisfactory when there is no certification requirement.

Practical/managerial implications: Based on these findings, the study concludes that skilled labour shortages and poor work output quality continue to be experienced in the South African construction industry when workers are unable to obtain formal certification for informal work experience acquired through years of practice on construction sites.

Contribution: It is recommended that the South African government establish proactive strategies in the form of a framework for use in evaluating, certifying and grading the informal expertise acquired by workers through years of practice. This recommendation seeks to ensure that the supply of certified craftsmen capable of undertaking and producing high-quality construction work meets demand.

\section{Introduction}

\section{Purpose of the study}

Increases in infrastructure spending since 2003 have seen a steady increase in the number of jobs as well as skills shortages that accompany such increases (Construction Industry Development [cidb], 2007). There have been various contributors to the increase in infrastructure development and construction activity within South Africa in recent years. These increases in infrastructure development came as a result of the Government's R372 billion-investment programme resulting from the Accelerated and Shared Growth Initiative for South Africa projects, as well as from the recent infrastructure developments that accompanied hosting the 2010 Soccer World Cup. These activities intensified the skilled labour crisis in South Africa (cidb, 2007). Skilled artisans were identified as critical for sustained growth by the government's Accelerated and Shared Growth Initiative for South Africa, as well as by other infrastructure projects (Mukora, 2008), and the skilled labour shortage may deter the rollout of the government's proposed Strategic Infrastructure Projects. 
The cidb (2007) views construction labour as all persons involved in physical construction work. This includes skilled and unskilled labour, which form the core labour component for the physical completion of the construction process. As a labour-intensive industry, construction heavily relies on the skills of its workforce (Agapiou, Price \& McCaffer, 1995). Skill can be described as the ability to perform particular tasks at a certain level of competence (Shah \& Burke, 2005). These competencies include the ability to perform a set of tasks, the ability to understand what others are doing and why, and the ability to adapt to changes and unforeseen circumstances (Department of Labour, 1997). Unskilled labour is more informal and unclearly defined, comprising labourers who lack relevant qualifications and various forms of education and learning (Shah \& Burke, 2005). Uwakweh and Maloney (1991) posit that developing countries often experience an abundance of unskilled and untrained labour.

Skills shortage has been a persistent problem and a critical factor facing the South African construction industry (Department of Education and Employment, 2000; Erasmus \& Breier, 2009; Makhene \& Thwala, 2009). Skills shortage can be described as an insufficient supply of suitably qualified workers willing to work under existing market conditions, particularly at prevailing wages. There have been extensive studies performed on the subject of skilled labour shortage in the construction industry and ways to alleviate the problem. These studies can be grouped into three categories. The first category identifies and discusses the various factors contributing to skilled labour shortages (see Ademeso, Izunnwanne \& Windapo, 2011). The second category addresses the impacts and consequences of skilled labour shortages (see cidb, 2007; Rasool \& Botha, 2011). The third category addresses the methods and means of dealing with the alleviation of the skilled labour crisis (see Agapiou et al., 1995; Awe, 2004; Department of Labour, 2007).

The few studies (see Cattell, 1997; Mukora, 2008; Makhene \& Thwala, 2009) that have focussed on the South African labour market have proposed a comprehensive and concise list of factors that match those found in the construction industries of developing countries. Ademeso et al. (2011) studied the Nigerian construction industry, and Agapiou et al. (1995) examined the UK construction industry. These studies both identified the cyclic nature of construction work and the image of the construction industry as a major contributing factor to the skills shortage. Factors offer an opportunity to understand the skilled labour shortage crisis in the construction industry. For example, the cyclic nature of construction markets has resulted in the industry experiencing significant fluctuations in output, which has influenced employment and training-level requirements (Agapiou et al., 1995; Morton \& Jagger, 1995). A recession in the construction industry is accompanied by job losses as companies downsize or go bankrupt because of a paucity of construction work (SA Construction News, 2011). Unemployed skilled construction workers then look for opportunities in other industries, as well as in cross-border construction industries (Mackenzie, Kilpatrick \& Akintoye, 2000). When the economy recovers, the skilled workers are reluctant to return to the construction labour market, thus exacerbating the skilled labour shortage (Agapiou et al., 1995).

According to cidb (2007), the issue of the quality and relevance of the training that students receive from training programmes (for example, Further Education and Training [FET] Colleges) and what is required of students has had an adverse effect on the skilled worker supply pipeline. This adverse effect is attributed to the characteristics of the education system, such as low educational standards, little provision for early childhood development and declining Grade 12 pass rates (Modisaotsile, 2012). Additionally, the fact that South Africa's maths and science results are extremely poor but required for admission to many of the programmes linked to certified trades, such as electrical and plumbing (Wedekind, 2015) has exacerbated the situation. Skill shortages are blamed on the education system, which is struggling to overcome decades of neglect and dysfunction under apartheid, when the education of black people was under-funded and of a poor quality, the decline in the apprenticeship system and the failure of substitute interventions, such as training through learnerships and FETs (Makhene \& Thwala, 2009).

Therefore, the study examines the skilled labour supply in South Africa and determines whether there is a significant relationship between the need for skills certification, skills shortage and quality of work output. The study proposes that there is a significant relationship between the need for labour certification and skill shortages and between the lack of certification and quality of work output in the construction industry. To conduct the study and test these propositions, the study undertakes an analytical review of the literature pertaining to skilled labour shortages. Thereafter, it collects empirical data through a mixed research method approach that includes interviews and questionnaires. The data collected are analysed using inferential and descriptive statistics. Finally, conclusions and recommendations that address the problems of the study are provided.

\section{The South African labour market and factors influencing the skilled labour supply}

The section provides an overview of the South African labour market with an emphasis on the skilled labour supply in the construction sector. It presents the current state of the skills supply and identifies holistic factors influencing the supply of skilled labour documented in the literature.

\section{Overview of the South African labour market}

The South African labour market is characterised by a predominance of an oversupply of unskilled workers and a shortage of skilled workers (Department of Labour, 2007). Despite the fact that a number of reforms have been implemented, the country still faces substantial skills shortages (Rasool \& Botha, 2011). According to Kraak (2008), the skills shortages experienced by the South African labour market are major impediments to economic growth and job 
creation in the country. The definition of skill is generic throughout the reviewed literature, with all sources attaching a qualification and a certain level of competence or expertise to a particular activity (Department of Labour, 2007; Shah \& Burke, 2005).

The construction industry is one of the largest employers in South Africa (Department of Labour, 2003). In 2005, the construction industry employed up to two thirds of all craftrelated workers (Mukora, 2008) and by 2011, 1031000 people were employed (Mayekiso, 2011) by the construction industry. Although the industry employs a large number of people, there was a decrease in formal employment between the early 1990s and 2001, with the construction industry losing more than 200000 jobs (cidb, 2007). The increase in infrastructure investment in 2003, in addition to the construction of the Guatrain and infrastructure for the 2010 FIFA World Cup, stimulated an increase in employment. This increased employment resulted in an increase in the demand for qualified managers, supervisors and artisans, which was hampered by a lag in graduation rates in construction and engineering (cidb, 2007).

In South Africa, skills shortages exist in many industries, including construction, and have been acknowledged by both the government and industry (Department of Labour, 2003). Brier (2009) states that there is a skills crisis because it takes longer to source skilled workers in the event of a surge in the demand for skills resulting from various infrastructure and large-scale projects.

\section{Investigation into factors influencing skills shortages}

It can be inferred from the literature that the factors influencing skills shortage include the construction industry's poor image, the role of the government, the quality and relevance of the training received by artisans, the ageing workforce, the cyclical nature of the demand for construction services, technological advancements, economic conditions and the need for certification. Firstly, the construction industry is perceived as a job of low social standing and as lacking in attractiveness because of its physical demands, long hours, remote work sites and nomadic lifestyle (cidb, 2007). Career artisans require people with hands-on experience rather than just supervisory experience. According to Mukora (2008), today's youth have no preference for hands-on labour and would rather work with computers. As a result, the industry has struggled to attract young people and has failed to replace the labour that has left the industry and to satisfy the increased demand for skilled labour (Ademeso et al., 2011; Cattell, 1997).

Government plays a significant role in the supply of artisans through the funding of training facilities (Mukora, 2008). For example, the South African government has attempted to increase the supply of artisans by launching the Sector Education and Training Authority, with the Construction Education and Training Authority as the primary institution driving this initiative in the construction industry (cidb, 2007). However, it has been found that the South African government has sought to over-regulate in some instances and has failed to ensure that various critical institutions of learning are functional enough to meet the demands of the industry (Mukora, 2008).

The cidb (2007) questions the skills taught in the various training programmes and posits that these skills do not make a significant contribution to the specialised skills required by the construction industry. According to Wedekind (2015), modern vocational programmes must prepare students for complex work, which demands a skills and knowledge mix that is different but not necessarily easier than those of school subjects.

Other factors mentioned in the literature as being responsible for skilled labour shortages in the construction industry include the ageing workforce; ageing members of the workforce who are near retirement are believed to affect the supply of labour because whilst fewer skilled workers are entering the job market, a significant number of qualified artisans, approximately 30\%, are leaving the job market (Mukora, 2008) and the cyclical nature of construction work, which has been noted as resulting in fluctuations in potential output, employment and training levels (Agapiou et al., 1995; Drucker \& White, 1996; Gruneberg, 1997). Furthermore, it is noted that changes in technological advancements in construction have resulted in changes in the demand for various types of skilled labour (Clarke \& Wall, 1998). According to Department of Education and Employment (2000), the development of new construction methods and processes is redefining the skill requirements of the industry. Meanwhile, according to Wells and Jason (2010), adverse economic conditions have caused construction companies to dispense with hiring labour permanently in favour of employing labour on a temporary basis. In South Africa, this tendency towards hiring temporary workers has resulted in the proliferation of labour brokers (Hemson, 2002; Skinner, 2002) and a lack of permanent employment and skills acquisition.

\section{Conceptual framework of the study}

The conceptual framework of the study is shown in Figure 1. This concept is based on the findings of previous studies by Cattell (1997) and Awe (2004). Cattell (1997) notes that the training that occurs in the informal sector is seldom certifiable because it is not a pre-requisite for obtaining employment in the informal sector. Awe (2004) views the lack of a requirement for compulsory certification as a barrier to the provision of skilled workers. This is because, in the non-compulsory certification segments, new entrants do not always see the value in completing an apprenticeship programme, and those who begin such a programme may be inclined to discontinue it during periods of high demand for skilled workers in the industry.

Figure 1 theorises that there is a relationship between skilled labour certification, labour shortages and the quality of work 


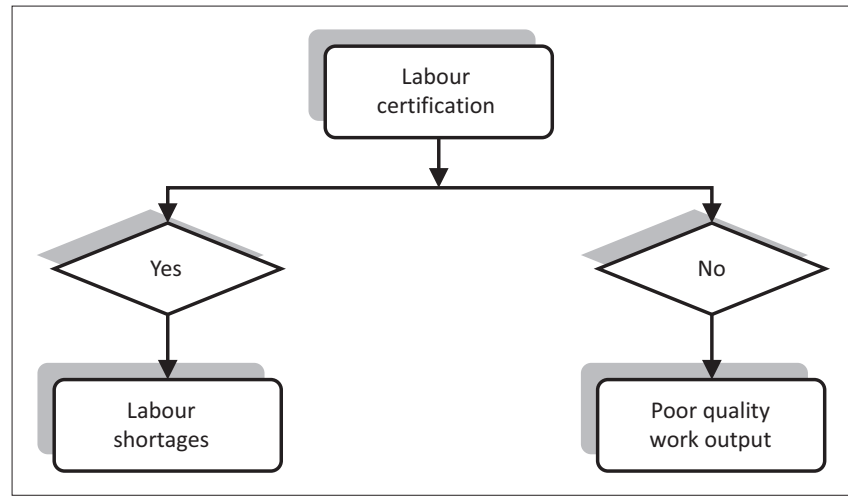

Source: Cattell, K.S. (1997). The development of black South African small-scale construction enterprises: Emerging contractors and the demand for formal training, Unpublished Report, Town and Awe E.M. (2004). The Nigerian technical education and manpower need the Town and Awe, E.M. (2004). The Nigerian technical education and manpower need in the construction industry: The missing link. Journal of Educational Technology and Management 5(4), 232-241

FIGURE 1: The concept of the study.

output. The figure proposes that construction services in which there is a requirement for skilled labour certification will experience shortages and that there will be poor quality work output in areas in which labour certification is not a requirement.

\section{Research methodology}

This study began with a literature review. According to Yin (1994), the main use of documentation is to corroborate and dispute evidence from other sources. Additionally, effective design of the research instrument requires a good understanding of the theories underpinning the research area. The study adopted a sequential mixed method research approach involving personal interviews and a questionnaire survey to collect empirical data. It was acknowledged from the outset that research surveys could attract identifiable disadvantages (Oo, Proust \& Lim, 2012), including low response rates and the potential to incorporate bias (sampling skews, researcher bias, a priori knowledge, etc.). Thus, measures were taken to address these shortcomings by using research triangulation (see Fellows \& Liu, 2008; Jick, 1979; Leedy \& Ormod, 2014). The intent of triangulation was not to replicate results but to obtain complementary findings that strengthen the deductions made(Morse, 1991). Questionnaires were distributed to a sample of contracting companies within the Western Cape Province of South Africa that are listed in Grades 2-9 of the cidb contractor register, supported by interviews to validate the findings made from the responses received.

The simple random sampling technique was used to select contractors from each grade to form a sample size of 460 respondents. At the end of the survey period, 63 responses were obtained, which translates into a $14 \%$ response rate. The survey gathered information pertaining to the investigation into the extent of skilled labour shortage and the factors influencing the shortage, and in-person and telephone interviews were used to examine factors that might have been overlooked in the survey and provide context to the preliminary results. The data obtained from the survey were analysed using descriptive statistics - the Mean Item Score (MIS) and inferential statistics - the Spearman's coefficient of rank correlation, $\rho$. A mean score will represent the results of the MIS, which will be a number ranging from 0 to 1 . The function of the MIS score is to rank the data collected from the rating scales used in the questionnaire. Equation 1 shows the formula of the MIS analytical technique:

$\mathrm{MIS}=\frac{5 \mathrm{M}_{5}+4 \mathrm{M}_{4}+3 \mathrm{M}_{3}+2 \mathrm{M}_{2}+1 \mathrm{M}_{1}}{5 \mathrm{x}\left(\mathrm{M}_{5}+\mathrm{M}_{4}+\mathrm{M}_{3}+\mathrm{M}_{2}+\mathrm{M}_{1}\right)}$

where: $\mathrm{M}_{1}=$ none; $\mathrm{M}_{2}=$ low $\mathrm{M}_{3}=$ average; $\mathrm{M}_{4}=$ high and $\mathrm{M}_{5}=$ very high .

Spearman's coefficient of rank correlation $\rho$ (rho) (see Equation 2) is a measure of the association between two variables, which is determined by the rank of the observations of the variables (Fellows \& Liu, 2008):

$\rho=1-\frac{6 \Sigma D^{2}}{n\left(n^{2}-1\right)}$

(where $D=$ difference between the ranks of two variables and $n=$ number of observations). The Spearman's correlation test is used to establish whether there is a relationship between the perceived level of labour shortage and the need for labour certification.

Eight telephone and personal interviews were undertaken. The interview questions sought to learn (1) the factors that determine the extent of the skilled labour shortage experienced by a particular company and (2) other factors perceived by the respondents to influence the severity of the skills shortage for various firms in the construction industry. The data collected were transcribed and analysed using thematic analysis. Themes emerging from the interviews were triangulated with findings drawn from the survey and used to gain insight into and contextualise the factors influencing skills shortages in the South African construction industry. These analysis methods ensure the internal validity of the research and increase the probability that the most likely explanations are provided for the observations made (Leedy \& Ormod, 2014).

To add reliability and accuracy to the data interpretation, Cronbach's alpha was used, which is a widely recognised approach to objectively measure the reliability of a survey instrument. The Cronbach's alpha reliability index provides a measure of the internal consistency of a questionnaire instrument in particular, the extent to which the items in a test or scale measure are the same concept or construct and their connection or relationship to the items within the test (Bland \& Altman, 1997). The acceptable values of alpha for consistency range from 0.70 to 0.95 , as defined in many texts (DeVellis, 2003; Tavakol \& Dennick, 2011). In the study, the alpha values for 'level of difficulty in obtaining skilled labour' and 'factors impacting skilled labour supply' are presented in Table 1.

Table 1 shows that the alpha values for each of the variables tested were greater than 0.70 , with an overall value of 0.908 . 
These results indicate that test results viz difficulty and skills impact factors were of high reliability and high interrelatedness and expressly capable of being measured on the same latent trait and scale.

\section{Findings}

In this section, the empirical data collected through the survey and the interviews conducted are presented, analysed and discussed.

\section{Distribution of respondents by contractor grade}

Table 2 shows the distribution of respondents in the survey by their contractor grade.

Table 2 reveals that the study sample consisted of mainly medium-sized contractors, followed by large and small-sized contractors.

\section{Perspectives of scarce skills}

The study sought to determine the level of difficulty experienced by employers in sourcing skilled labour. The data obtained in this regard are presented in Table 3.

Table 3 indicates that contractors have more difficulty in sourcing carpenters, fitters, electricians and plumbers than they do in sourcing bricklayers, tilers, plasterers and painters. Some contractors indicated that there are other trades not listed in the questionnaire that they had difficulty in finding,

TABLE 1: Cronbach's alpha test results for difficulty in obtaining skilled labour and factors impacting skilled labour supply.

\begin{tabular}{lcc}
\hline Variable & Number of items & Cronbach's alpha \\
\hline Difficulty in obtaining skilled labour & 10 & 0.912 \\
Factors impacting skilled labour supply & 9 & 0.878 \\
Overall Cronbach's alpha & - & 0.908 \\
\hline
\end{tabular}

TABLE 2: Distribution of respondents by contractor grade.

\begin{tabular}{|c|c|c|c|c|c|c|c|c|c|}
\hline \multirow{2}{*}{$\frac{\text { Size }}{\text { cidb grade }}$} & \multicolumn{3}{|c|}{ Small contractor } & \multicolumn{2}{|c|}{ Medium } & \multicolumn{3}{|c|}{ Large contractor } & \multirow{2}{*}{$\frac{\text { Total }}{-}$} \\
\hline & 2 & 3 & 4 & 5 & 6 & 7 & 8 & 9 & \\
\hline Frequency & 2 & 1 & 4 & 30 & 16 & 7 & 1 & 2 & - \\
\hline Percentage & \multicolumn{3}{|c|}{11.11} & \multicolumn{2}{|c|}{73.02} & \multicolumn{3}{|c|}{15.87} & 100 \\
\hline Total & \multicolumn{3}{|c|}{7} & \multicolumn{2}{|c|}{46} & & 10 & & 63 \\
\hline
\end{tabular}

cidb, Construction Industry Development Board. for example, instrumentation technicians, who take care of the plant on site; heating, ventilating and air conditioning technicians; steel fixers; shutter hands and sheet metal workers.

\section{Trades in which skilled labour must be certified before employment}

Table 4 presents data collected on the trades that employers require some form of labour certification for before employment. It can be seen from Table 4 that although $88 \%$ of the respondents affirmed that their companies require electricians to be certified before employment, $19 \%, 12 \%, 8 \%$ and $6 \%$ require that bricklayers, tilers, painters and plasterers be certified, respectively.

\section{Perceived factors affecting the skilled labour supply}

The study sought to determine the factors perceived by the respondents as contributing to skilled labour supply shortages. The data collected in this regard are presented in Table 5. Table 5 shows that from a ranking perspective, respondents view economic conditions, lack of basic education and compulsory certification as key factors in creating skilled labour supply shortages.

\section{Test of the relationship between labour certification requirement and labour shortage}

This study sought to test the proposition that there is a significant relationship between the need for labour certification and the perceived level of skill shortages experienced in the South African construction industry. Data presented in Tables 3 and 4 were used to calculate the difference in rank, which was established as 42 . Substituting this figure into the formula for calculating the Spearman's rank correlation coefficient in Equation 2:

$\rho=\frac{1-6 \times 42}{10\left(10^{2}-1\right)}=1-0.25=0.75$

[Eqn 3]

The observed value of $\rho$ (rho) (0.75) is larger than the tabulated critical value (0.65) and is therefore significant at the 0.05 level for the two-tailed test. Based on these findings, it can be concluded that the need for trade certification significantly contributes to the perceived level of skills

TABLE 3: Level of difficulty experienced in sourcing skilled labour.

\begin{tabular}{|c|c|c|c|c|c|c|c|c|}
\hline \multirow[t]{3}{*}{ Trade } & \multicolumn{5}{|c|}{ Frequency } & \multirow[t]{3}{*}{ Total response } & \multirow[t]{3}{*}{ Mean Item Score } & \multirow[t]{3}{*}{ Rank } \\
\hline & \multicolumn{5}{|c|}{ None - - } & & & \\
\hline & 1 & 2 & 3 & 4 & 5 & & & \\
\hline Carpenters & 6 & 8 & 11 & 14 & 13 & 52 & 0.68 & 1 \\
\hline Fitters & 4 & 7 & 12 & 16 & 7 & 46 & 0.67 & 2 \\
\hline Electricians & 8 & 13 & 12 & 18 & 8 & 59 & 0.62 & 3 \\
\hline Plumbers & 7 & 10 & 14 & 13 & 8 & 52 & 0.62 & 3 \\
\hline Roofers & 7 & 13 & 12 & 13 & 6 & 51 & 0.59 & 6 \\
\hline Bricklayers & 9 & 16 & 12 & 10 & 7 & 54 & 0.56 & 7 \\
\hline Tilers & 7 & 10 & 24 & 8 & 3 & 52 & 0.56 & 7 \\
\hline Plasterers & 8 & 12 & 18 & 6 & 6 & 50 & 0.56 & 7 \\
\hline Painters & 12 & 18 & 10 & 6 & 5 & 51 & 0.50 & 10 \\
\hline
\end{tabular}


shortages in the construction industry. Workers may have the necessary knowledge or skills, but they need a certificate to prove it.

\section{Differences in the quality of work output between certified and uncertified artisans}

The study sought to determine whether there are any differences in the work produced by certified and uncertified artisans. The responses provided to this enquiry are shown in Figure 2. For a number of the trades - electricians, plumbers, roofers, fitters and welders - the respondents experienced high to very high differences in the quality of work produced by artisans who are certified and those who are not.

Figure 2 reveals that the respondents experienced no significant differences in the quality of work produced between tradesmen who are versus those who are not certified in the bricklaying, plastering and painting trades.

\section{Interview findings}

The factors influencing skilled labour supply that were identified in the interviews matched those identified from the questionnaire and literature surveys. Prominent amongst these factors were the lack of education, economic conditions, compulsory certification and the ageing work force. However, the interviews did provide additional insight into factors currently relevant to the skilled labour supply in South Africa. The interviewees also revealed that:

- All companies in the construction industry need skilled labour as part of their work force. This is to ensure that the quality of the work they do is consistent and of the

TABLE 4: Trade in which employing company requires labour to be certified.

\begin{tabular}{|c|c|c|c|c|c|}
\hline \multirow[t]{2}{*}{ Trade } & \multicolumn{2}{|c|}{ Frequency } & \multirow[t]{2}{*}{ Total response } & \multirow{2}{*}{$\begin{array}{l}\text { Mean response } \\
\text { average }\end{array}$} & \multirow[t]{2}{*}{ Rank } \\
\hline & Yes & No & & & \\
\hline Electricians & 52 & 7 & 59 & 0.88 & 1 \\
\hline Fitters & 32 & 14 & 46 & 0.70 & 2 \\
\hline Plumbers & 34 & 17 & 51 & 0.67 & 3 \\
\hline Welders & 33 & 18 & 51 & 0.65 & 4 \\
\hline Roofers & 24 & 28 & 52 & 0.46 & 5 \\
\hline Carpenters & 13 & 38 & 51 & 0.25 & 6 \\
\hline Bricklayers & 10 & 42 & 52 & 0.19 & 7 \\
\hline Tilers & 6 & 45 & 51 & 0.12 & 8 \\
\hline Painters & 4 & 48 & 52 & 0.08 & 9 \\
\hline Plasterers & 3 & 48 & 51 & 0.06 & 10 \\
\hline
\end{tabular}

required standard. Therefore, skilled labour plays an integral role in the success of a construction firm because it affects the firm's profitability.

- The number of skilled labourers a company needs is related to its size and the value of the tenders it has won. That is, large companies will have a different scale of low-, medium- and high-skilled labour needs when compared to a small company that normally works as a sub-contractor. According to participant 36:

'basically, it's a function of costs and profits. For example, a big company like Murray and Roberts might have a pool of skilled workers employed full time, while a small subcontractor will only have a few and employ more workers on an as needed basis. A company ideally wants to employ the number of labour as related to their needs, i.e., whether they have work or not.' (Participant 36, male contractor, Grade 6)

- The issue of labour brokers (e.g. Colven Nkomo) as a factor influencing skilled labour supply was also mentioned. According to participant 22:

'labour brokers generally have both skilled and unskilled labour they can call on and employ when they are needed by the companies they service. These workers are not employed by the company but are outsourced and that is why some companies prefer this option because it is easier and cost effective. However, due to the consistency and quality, which is needed in the work produced, they won't entirely depend on this source of skilled labour, companies will need to have a few of their own skilled labourers to ensure quality and consistency of their work.' (Participant 22, female contractor, Grade 7)

- The subject of labour certification and the problems involved in obtaining certification were also addressed. A respondent revealed that there are few people who are certified in any particular construction skill because there are no recognised training centres that have a high level of skill to pass on to prospective students. According to the respondent, the question of differences between the quality of work output of certified and uncertified artisans is irrelevant because skilled artisans belong to an older generation, and much of the training occurs in contracting organisations.

- Another factor that emerged in the interviews is the procurement targets requirement in government contracts. Government requires a certain percentile of labour to be employed from the area where the project is located. Broad-Based Black Economic Empowerment sub-contractors and suppliers must be hired, and a certain

TABLE 5: Factors impacting on skilled labour supply.

\begin{tabular}{|c|c|c|c|c|c|c|c|c|}
\hline \multirow[t]{3}{*}{ Factors } & \multicolumn{5}{|c|}{ Frequency } & \multirow[t]{3}{*}{ Total response } & \multirow{3}{*}{$\begin{array}{l}\text { Mean Item } \\
\text { Score }\end{array}$} & \multirow[t]{3}{*}{ Rank } \\
\hline & \multicolumn{5}{|c|}{ 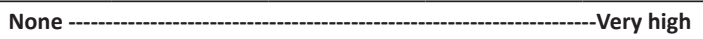 } & & & \\
\hline & 1 & 2 & 3 & 4 & 5 & & & \\
\hline Lack of basic education & 2 & 5 & 8 & 24 & 22 & 61 & 0.793 & 1 \\
\hline Economic conditions & 1 & 4 & 10 & 28 & 18 & 61 & 0.790 & 2 \\
\hline Compulsory certification & 3 & 9 & 17 & 15 & 17 & 61 & 0.711 & 3 \\
\hline Ageing work force & 2 & 9 & 17 & 22 & 11 & 61 & 0.702 & 4 \\
\hline Cyclical nature of construction & 2 & 4 & 26 & 18 & 9 & 59 & 0.695 & 5 \\
\hline Technological challenges & 3 & 9 & 17 & 19 & 12 & 60 & 0.693 & 6 \\
\hline Low income & 2 & 7 & 25 & 17 & 9 & 60 & 0.680 & 7 \\
\hline Health and safety requirements & 3 & 18 & 14 & 19 & 8 & 62 & 0.635 & 8 \\
\hline Perception of the industry & 7 & 8 & 18 & 19 & 6 & 58 & 0.631 & 9 \\
\hline
\end{tabular}




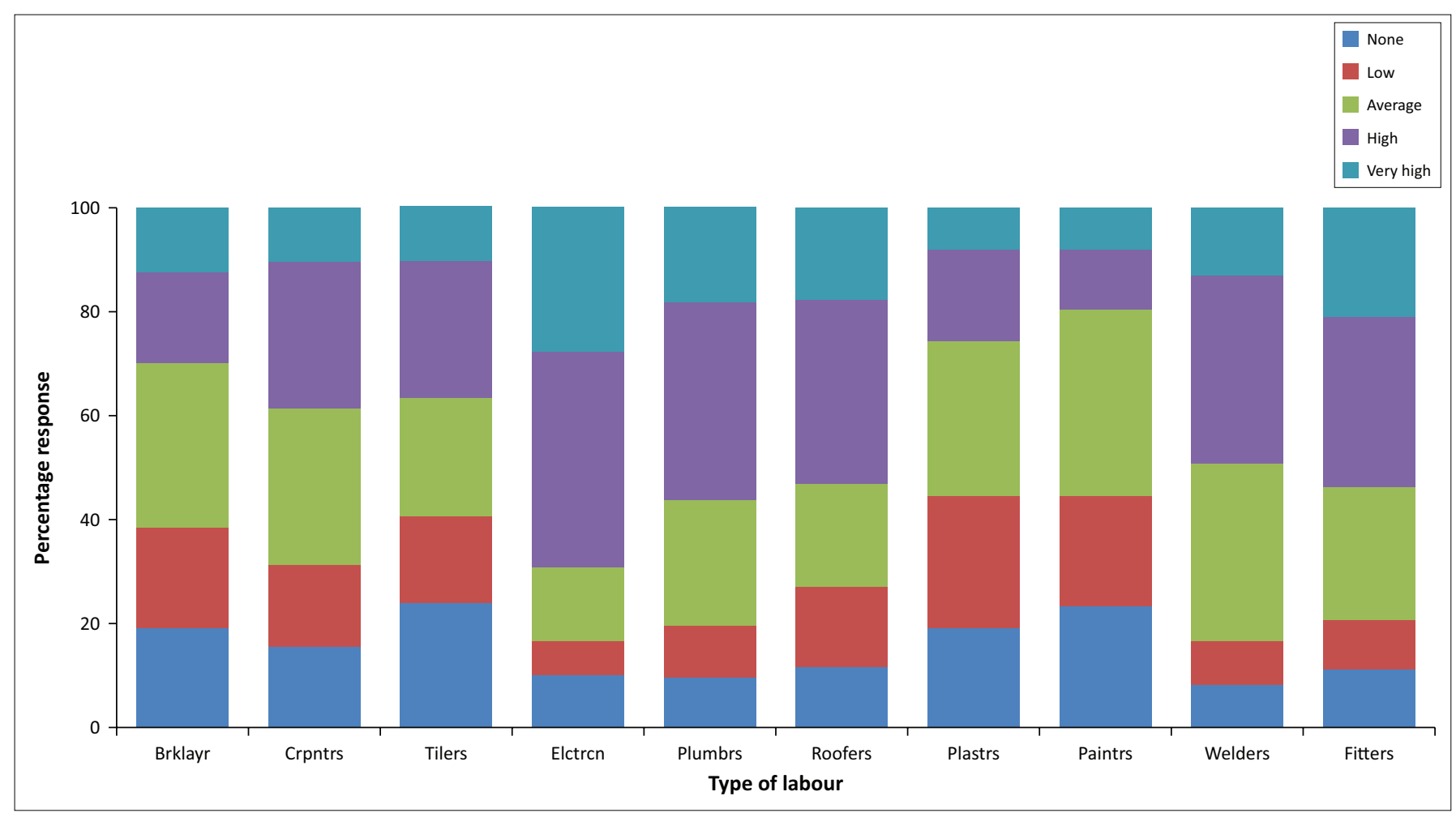

Brklayr, bricklayers; Crpntrs, carpenters; Elctrcn, electricians; Plumbrs, plumbers; Plastrs, plasterers; Paintrs, painters.

FIGURE 2: Differences in quality of work output between certified and uncertified artisans.

amount of money must be put aside for training some of those workers. According to a participant 47:

'this may to some extent, affect the amount of skilled labour a company will choose to have, if they have to utilise local labour and Broad-Based Black Economic Empowerment sub-contractors.' (Participant 47, male contractor, Grade 9)

\section{Discussion of findings}

The survey and interview data were triangulated to ensure the validity that construction firms require skilled labour as part of their workforces. Skilled labour is required to ensure that the quality of work these workers do is consistent and of the required standard. Therefore, skilled labour plays an integral role in the success of a construction firm. The results showed that the trades in which skills are scarce and in which contractors experience difficulty in sourcing workers are those with a technical nature, such as plumbers, electricians and carpenters. These artisans require greater levels of accuracy, a more rigorous education and training process and certification (Wedekind, 2015). The study found that the shortage in skilled artisans is correlated to the need for certification. The key factors perceived to contribute to the level of skilled labour shortages are the lack of basic education, which may affect the ability of an individual to enter FET colleges, which is suggestive of a poor educational system, economic conditions and compulsory certification. The study results also confirmed the proposition that there is a large difference in the quality of work output between certified and uncertified artisans in the electrical, plumbing, roofing, fitting and welding trades. These trades are the trades in which firms often require certification.
The findings of the study match the findings of studies by Awe (2004) - the need for certification; Wells and Jason (2010) - economic conditions; Agapiou et al. (1995), Drucker and White (1996), Gruneberg (1997) and Ademeso et al. (2011) - the cyclical nature of the demand for construction services; and Mukora (2008) - an ageing workforce. There were no previous studies that considered lack of basic education as a factor influencing the skilled labour supply in the construction industry or that established a relationship between the need for compulsory trade certification and scarce labour skills, which are key findings of the study. However, Wedekind (2015) contends that the skill shortage in South Africa is linked to a lack of formal schooling.

\section{Conclusion and further research}

The paper examined the skilled labour supply in the South African construction industry and determined whether there is a relationship between notable factors, such as trade certification, quality of work output and scarce labour skills. The study used a mixed method research approach to elicit empirical data from contractors based in the Western Cape Province of South Africa. It emerged that there were skilled labour shortages in the construction industry, particularly within the electrical, plumbing, welding and fitters' trades, and that these shortages are correlated with the need for certification and that there is a difference between the quality of work produced by certified skilled workers and uncertified workers. It was also found that the key factors perceived to affect the skilled labour supply are the lack of basic education, economic conditions and the need for certification from a ranking perspective. Based on these findings, the study 
concludes that South Africa will continue to experience skill shortages, particularly amongst the highly technical trades in which accuracy is required, such as for electricians, plumbers, roofers, fitters and welders, if the basic educational system is not strengthened, if this category of workers fails to become certified and if there is no framework for evaluating the expertise acquired by workers informally through years of experience on job sites.

The paper recommends that the South African government establish proactive strategies in the form of subsidised technical and vocational schools for training tradesmen and for improved secondary education to increase the likelihood that capable individuals will attend FET colleges. It is also recommended that future research examine at least one third of the provinces in South Africa and the obstacles affecting the training and certification of construction industry artisans. The study is limited to the Western Cape Province of South Africa and therefore care should be taken when generalising its results to the general contractor population in South Africa.

\section{Acknowledgements}

The author would like to acknowledge the assistance of the following people in conducting the survey and interviews: Dominic Benn, Bulelani Gwabeni and Tatenda Kanyangarara.

\section{Competing interests}

The author declares that she has no financial or personal relationships which may have inappropriately influenced her in writing this article.

\section{References}

Ademeso, O.S., Izunnwanne, O., \& Windapo, A.O. (2011). Examining factors contributing to shortage of skilled workers in the construction industry. NMMU Construction Management 40 Conference Proceedings, 27-29 November (pp. 204-213). Protea Marine Hotel, Port Elizabeth, South Africa: Department of Construction Management, NMMU.

Agapiou, A., Price, A.D.F., \& McCaffer, R. (1995). Planning future construction skill requirements: Understanding labour resources. Construction Management and Economics, 13(2), 149-161.

Awe, E.M. (2004). The Nigerian technical education and manpower need in the construction industry: The missing link. Journal of Educational Technology and Management, 5(4), 232-241.

Bland, J.M., \& Altman, D.G. (1997). Statistics notes: Cronbach's alpha. British Medical Journal, 314, 572.

Brier, M. (2009). Skill shortages in South Africa: Case studies of key professions. Cape Town: HSRC Press, pp. 1-33.

Cattell, K.S. (1997). The development of black South African small-scale construction enterprises: Emerging contractors and the demand for formal training, Unterpisished Report, Department of Construction Economics \& Management, University of Cape Town, Cape Town.

Clarke, L., \& Wall, C. (1998). A blueprint for change: Construction skills training in Britain. Bristol: Policy Press.

Construction Industry Development Board (cidb). (2007). Skills for infrastructure delivery in South Africa: The challenge of restoring the skills pipeline. Pretoria: cidb.

Department of Education \& Employment (DfEE). (2000). An assessment of skill need in construction and related industries, skill dialogues: Listening to employers research papers. London: DfEE and Business Strategies Ltd.
Department of Labour (DoL). (1997). Green Paper: Skills Development for Economic and Employment Growth in South Africa. Pretoria: DoL.

Department of Labour (DoL). (2003). State of skills in South Africa. Pretoria: DoL.

Department of Labour (DoL). (2007). Development implementation strategy report. Pretoria: DoL.

DeVellis, R. (2003). Scale development: Theory and application, Thousand Oaks, CA: Sage.

Drucker, J., \& White, G. (1996). Research methods for construction. (2nd edn.). Oxford: Blackwell Science Ltd.

Erasmus, J., \& Breier, M. (2009). Skills shortages in South Africa, case studies of key professions, World Rights Publishers, ISBN 978-07969-2266-3. Retrieved April 02, 2012, from http://www.hsrcpress.ac.za/product.php?productid=2257

Fellows, R., \& Liu, A. (2008). Research methods for construction. (3rd edn.). West Sussex, UK: Wiley-Blackwell.

Gruneberg, S.L. (1997). Construction economics - An introduction. London: Macmillan, pp. 21-36.

Hemson, D. (2002). Breaking the impasse, beginning the change: Labour market, unions and social initiative in Durban. In V. Padayachee, \& B. Freund (Eds.), D(urban) Vortex. South African city in transition, (pp. 195-221). Pietermaritzburg: University of Natal Press.

Jick, T.D. (1979). Mixing quantitative and qualitative methods: Triangulation in action. Administrative Science Quarterly, 24(4), 602-611.

Kraak, A. (2008). The education-economy relationship in South Africa, 2001-2005. In A. Kraak, \& K. Press (Eds.), Human resources development review 2008, education employment and skills in South Africa (pp. 1-25). Cape Town: HSRC Press.

Leedy, P.D., \& Ormrod, J.E. (2014). Practical research planning and design. (10th edn.). Essex, England: Pearson Education Ltd.

Mackenzie, S., Kilpatrick, A.R., \& Akintoye, A. (2000). UK construction skills shortage response strategies and an analysis of industry perceptions. Construction Management and Economics, 18(7), 853-862.

Makhene, D., \& Thwala, W.D. (2009). Skilled labour shortages in construction contractors: A literature review. Johannesburg: University of Johannesburg.

Mayekiso, L. (2011). Annual labour market Bulletin. Pretoria: Department of Labour.

Modisaotsile, B.M. (2012). The falling standard of basic education in South Africa. Pretoria: Africa Institute of South Africa.

Morse, J. (1991). Approaches to qualitative-quantitative methodological triangulation. Nursing Research, 40(2), 120-123.

Morton, R., \& Jagger, D. (1995). Design and economics of building April 2010-March 2011. London: E \& FN Spon.

Mukora, J. (2008). Scarce and critical skills research report, Pretoria: Department of Labour.

Oo, B., Proust, G., \& Lim, B. (2012). An empirical studies of communication competence of Civil Engineering graduates - Implication of engineering curriculum. Proceedings of Joint CIB International Symposium of W055, W065, W089, W118, TG76, TG 78, TG81, and TG84, 26-29 June (307-317). Montreal, Canada. International Council for Research and Innovation in Building and Construction $(\mathrm{CIB})$

Rasool, F., \& Botha, C.J. (2011). The nature, extent and effect of skilled shortages on skills migration in South Africa. SA Journal of Human Resource Management, 9(1), 1-12.

SA Construction News. (2011). SA construction firms look to Africa for growth, Commercial Property News. Retrieved September 21, 2012, from http://www. saconstructionnews.co.za

Shah, C., \& Burke, G. (2005). Skills shortages: concepts, measurement and policy responses. Australian Bulletin of Labor, 31(1), 44-71.

Skinner, C. (2002). Understanding formal and informal economy labour market dynamics: A conceptual and statistical review with reference to South Africa. School of Development Studies, University of Natal, Durban, p. 25.

Tavakol, M., \& Dennick, R. (2011). Making sense of Cronbach's alpha, editorial. International Journal of Medical Education, 2, 53-55.

Uwakweh, B.O., \& Maloney, W.F. (1991). Conceptual model for manpower planning for the construction industry in developing countries. Construction Management and Economics, 9(5), 451-465.

Wedekind, V. (2015). Vocational training is not an easy alternative to formal schooling, The Conversation, July. Retrieved July 10, 2015, from http://www.theconversation. com/

Wells, J.S., \& Jason, A. (2010). Employment relationships and organizing strategies in the informal construction sector. African Studies Quarterly, 11(2\&3), (Spring), 107-124

Yin, R.K. (1994). Case study research: Design and methods. (2nd edn.). London: Sage. 